six main regions, i.e. Northern Africa, North-Eastern Africa, Western Africa, Central Africa, Eastern Africa, and Southern Africa. A general section arranged by subject precedes the listing by country divisions. Periodicals have been listed alphabetically by title and newspapers by geographic area. An index, primarily of authors but containing some subjects, has been added. The price of the catalogue is $\$ 6.00$ and it may be ordered from The Moorland Foundation, Howard University Library, Washington I, D.C.

\title{
Nomination du Nowveau Directeur du Musée Royal du Congo Belge à Tervueren
}

M. LuCien CAHEN a été nommé aux fonctions de directeur du Musée royal du Congo belge à Tervueren, succédant au professeur Frans M. Olbrechts. Ingénieur des mines et géologue, chargé de cours à l'Université de Bruxelles, membre associé de l'Académie royale des Sciences coloniales, M. Cahen a passé une dizaine d'années au Congo et a commencé sa carrière au Musée royal du Congo belge en 1947 . Il est l'auteur de nombreuses publications scientifiques.

\section{House-ownership Scheme for Africans at Lusaka}

A PRIVATE firm of building contractors is at present engaged on a $f \mathrm{I}, 000,000$ privately financed house-ownership scheme for Africans at Lusaka, Northern Rhodesia. It is the first private venture of its kind here, though the Southern Rhodesian Government started a similar scheme two years ago. Private building contractors have not, up to now, undertaken speculative building for Africans in the Federation, since it was thought there were not enough who could afford to buy their own houses. A total of 1,000 houses, costing from $f_{5} 50$ to $£_{1}, 500$, will be built in the 632 -acre township which is being developed; all the houses will be available for purchase under a twenty-year agreement with a building society and will involve moderate mortgage charges. The township will also contain schools, public open spaces, trading areas, service industries, public buildings, churches, sporting facilities, including a stadium, and a civic centre with a town hall and banqueting-rooms.

\section{'Seminar für Afrikanistik' at Cologne}

A Department of African Studies was founded at the University of Cologne in March 195 8. Dr. Oswin Köhler, who studied under the late Professor Westermann at the University of Berlin, is in charge of the Department. From 1954 to 1957 Dr. Köhler was in the service of the Government of the Union of South Africa, and carried out field-work in South-West Africa in ethnology and linguistics.

\section{A New English Edition of the Ethiopic Liturgy}

A New English rendering of the Ethiopic liturgy, based on the 'Low Mass' form of the Liturgy of the Apostles, has recently been published. It is a translation of a text submitted in manuscript by Abba Petros Hailu; after the rite of introductory preparation there follows the Pro-Anaphora (Ordinary of the Mass) and the Anaphora (Canon of the Mass). The liturgy may be obtained from Abba Tito Lepisa, the Catholic Cathedral, Addis Ababa, Ethiopia; the price is U.S. \$1.00.

\section{'Analysis of a Social Situation in Modern Zululand'}

TheSE essays by Professor Max Gluckman, originally published in Bantu Studies in 1940 and in its successor African Studies in 1942, have now been collected together as number twenty-eight in the Rhodes-Livingstone Papers, by the Rhodes-Livingstone Institute. Analysis of a Social Situation in Modern Zululand is published by the Manchester University Press and costs 8s. 6d; the publishers in the U.S.A. are Humanities Press Inc., 303 Fourth Avenue, New York, Io. 